\title{
Science Academies' Refresher Course on Environmental Biology
}

\author{
1 - 15 February 2016 \\ at Central University of Punjab, Bathinda 151001 \\ Sponsored by Indian Academy of Sciences, Bengaluru \\ Indian National Science Academy, New Delhi \\ The National Academy of Sciences, India, Allahabad
}

\begin{abstract}
Central University of Punjab, Bathinda (CUPB) is a new Central University established through an act of parliament in 2009. The university is consistently ranked at No. 1 among newly established central universities by a number of independent research citation indices, including Scopus, ISI Web of Science and Research Gate ${ }^{\circledR}$. CUPB's core area of research focus is Environmental Biology and the campus offers avant garde research facilities for the modern research in this field. Infrastructure include 96 capillaries DNA Sequencer, FESEM with EDX, CLSM with FCS and Live Cell Imaging, FTIR, AAS, GCMS, Gradient PCR and RT-PCR machines, Automatic karyotyping workstation and so on.
\end{abstract}

The UGC has notified (F-3/1-2009) that teachers in Universities and Colleges attending two-week Refresher Courses are entitled to be considered for promotion. This two-week refresher course on environmental biology will cover recent advances in fields such as RNAi technology, soil and rhizosphere health, biogeochemistry, environmental pollution, functional genomics, plant genomics and biochemistry, and molecular medicine. All resource persons will be eminent scientists working in these fields who are the fellows of the national science academies. The participants of the refresher course will have hands-on experience with all of the advanced facilities available in the CUPB. Applications are invited from teachers with experience in teaching postgraduate courses in Life Sciences or in Environmental Sciences. Applications from highly motivated graduate students will also be considered. Maximum 30 applications will be considered. Teachers who wish to participate in the refresher course may apply through proper channel. It is also essential to submit a brief statement (between 250 and 500 words) as to why they think the Course will help to improve their classroom teaching of Life Science/ Environmental Science. There will be no application fee/registration fee.

Applications should be submitted ONLINE by clicking the following link:

http://web-japps.ias.ac.in:8080/Refreshcourse/RCUP.jsp

A print copy of the application forwarded by the head of the institution must also be sent by speedpost to the Course Coordinator before 15 January 2016. Outstation candidates will be provided local hospitality and round trip bus/train (3 tier AC) fare by the shortest route as per rules.

Course Director: Professor R.K. Kohli, FASc, FNA, FNASc, FNAAS, JC Bose National Fellow

Course Co-Director: Prof. P. Ramarao, Dean, Academic Affairs

Course Coordinator:Dr Felix Bast (e-mail: felix.bast@gmail.com). 